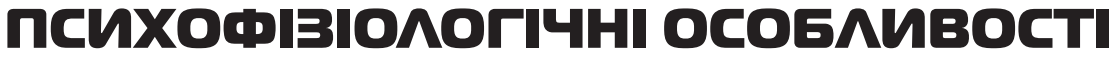 ПРОГНОЗУВАННЯ НААЙНОСТІ ПРОФЕСІЙНӦ̈

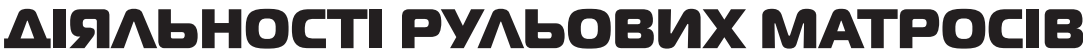 ЗА ПОКАЗНИКАМИ РЕАКШЇ НА РУХОМИЙ ОБ'ЕКТ
}

\author{
Швешь А. В., ^ук'янчук I. А.
}

\author{
Науково-Аосліцний інститут проблем військової медишини Української військово-медичної \\ ака $\Delta$ емії, м. Київ
}

Bcmyn. Дослідження, спрямовані на досягнення високої надійності професійної діяльності операторів і, зокрема, рульових матросів, є актуальними в сучасній медицині, психофізіології та ергономіці праці.

Мета дослідження. На основі дослідження закономірностей функціонування центральної нервової системи при впливі інформаційного навантаження різного ступеня інтенсивності розробити підходи до прогнозування надійності операторської діяльності рульових матросів за характеристиками реакції на рухомий об'єкт.

Матеріали та методи дослідження. Для виконання даної роботи було обрано групу рульових матросів (30 чоловіків віком 22-24 роки). Для визначення характеристик реакції на рухомий об'єкт (РРО) при різному інформаційному навантаженні було створено спеціальну комп'ютерну програму. Як характеристику надійності операторської діяльності обрано показник точності РРО залежно від вчасності реакції, напрямку руху маркера та різного рівня інформаційного навантаження.

Результати. У рульових матросів виявлено достовірне погіршення показників точності РРО запізнілого типу не залежно від напрямку руху маркера при зростанні інформаційного навантаження. Виділено суттєво різні підгрупи осіб за рівнем точності РPO, які мають різні стратегії підтримки надійного виконання операторської діяльності, що обумовлено особливостями прояву міжпівкульної асиметрії та кількісною і якісною структурою взаємозв'язків показників точності РРО при різній інтенсивності інформаційного навантаження. Наявність превалювання гальмівних процесів у центральній нервовій системі чинить достовірний негативний вплив на надійність переробки інформації.

Висновки. 1. За параметрами точності РРО запізнілого типу виділено дві, суттєво різні підгрупи осіб, які відрізнялись виразніше в умовах надмірного інформаційного навантаження. 2. Виявлено існування різних механізмів та стратегій забезпечення високої надійності переробки інформації, в основі яких лежать прояви врівноваженості чи неврівноваженості патернів міжпівкульної асиметрії нервових процесів у головному мозку та різна напруженість регуляторних процесів у центральній нервовій системі відповідно в осіб з кращими (60\%) та гіршими (40\%) показниками точності РРО. 3. Розроблені роз'язувальні правила за показниками РРО достатні для прогнозування високої надійності професійної діяльності рульових матросів з точністю 96,66 \%.

Ключові слова: надійність професійної діяльності, реакція на рухомий об'єкт, рульові матроси

\section{Вступ}

Вивчення надійності професійної діяльності є завданням, яке не втрачає своєї актуальності з плином часу $[1,10]$. Це пов'язано як з науково-технічним прогресом, який значно ускладнюе сучасні технології, що, у свою чергу, віддзеркалюється на складності роботи, так і з тенденцією підвищення рівня нервово-емоційного напруження людини в сучасних умовах діяльності, обумовлених соціальними, економічними, екологічними та іншими причинами.

Так, у найближчій перспективі в зв'язку з напруженою демографічною ситуацією в Україні та значним зниженням рівня здоров'я населення, особливо в молодому віці, виникають суттеві обмеження щодо відбору контингенту на контрактну службу.
Зокрема, це стосується операторських видів спеціальностей корабельних працівників. Багаторічний досвід здійснення заходів з прогнозування професійної придатності в армії США свідчить про його високу ефективність. Так, практичне впровадження методів психодіагностики забезпечує до 33 \% приросту продуктивності праці, у $2-3$ рази знижуе плинність кадрів, зменшуе аварійність з вини персоналу на 40-70 \% та забезпечує зниження витрат на підготовку фахівців на 30-40 \% [19].

У зв'язку з цим, по-перше, виникають складності в наборі на контрактну службу, по-друге, відібрані контингенти мають у своєму складі осіб зі зниженим рівнем здоров'я та погіршеними психофізіологічними характеристиками, наслідком чого $е$ 
зниження надійності їхньої діяльності. Разом з цим, різноманітність і складність умов сучасної військової служби підвищує ступінь відповідальності за якість діяльності та «вартість» помилок $[1,4,20]$. Багато хто з військовослужбовців, будучи чудовими професіоналами за звичайних умов служби, за своімми психологічними та психофізіологічними якостями виявилися не в змозі справитися з функціональними обов'язками при роботі в екстремальних умовах. Так, наприклад, при ліквідації наслідків Уфімської катастрофи психофізіологами відмічено, що в $98 \%$ рятівників так чи інакше спостерігався страх від побаченого, у 62 \% - розгубленість, слабкість у кінцівках, у 20 \% - ознаки передзапаморочення тощо [3].

Відомо, що ефективність та надійність діяльності операторів визначаються насамперед рівнем розвитку психофізіологічних функцій, тому оцінка стану саме цих функцій має складати основну компоненту досліджень при проведенні будь-якого професійного добору [11].

Досвід багаторічних психофізіологічних досліджень людини свідчить, що універсальними інди каторами успішності операторської діяльності є швидкість і точність реакцій [18]. Показником досконалості переважної кількості видів діяльності, а особливо операторської, є іiі своєчасність. Дослідження [17] переконливо доводять, що оволодіння діями та рухами закінчується формуванням безпомилкового сприйняття їхньої часової структури. Точність, легкість, пластичність дій людини характеризуються відповідною часовою структурою виконання завдань [2]. Таким чином, одним 3 найважливіших моментів дослідження діяльності військовослужбовців у різних, у тому числі й шкідливих умовах праці є вивчення темпоральних параметрів організації іхніх реакцій, що є інформативними характеристиками надійності виконання їхніх службових обов'язків [15].

Тому оцінка надійності професійної діяльності корабельних спеціалістів Військово-Морських Сил Збройних Сил України (ВМС ЗС України) та якостей, які на сучасному рівні необхідні для ефективного іiі здійснення, а також виявлення особливостей розумової діяльності моряків в ситуаціях високого нерівномірного інформаційного навантаження є актуальними та дозволять удосконалити систему психофізіологічного супроводу професійної діяльності корабельних спеціалістів ВМС 3С України шляхом контролю та прогнозування надійності іхньої професійної діяльності.

Мета дослідження - на основі дослідження закономірностей функціонування центральної нервової системи (ЦНС) при впливі інформаційного навантаження різного ступеня інтенсивності розробити підходи до прогнозування надійності операторської діяльності рульових матросів за показниками $\mathrm{PPO}$

\section{Матеріали та методи дослідження}

Об'єктом дослідження була група рульових матросів (30 чоловік віком від 22 до 24 років). Обстеження проводили в однаковий час з 9:00 до 14:00 на базі Академії військово-морських сил імені П. С. Нахімова.

Оскільки як найінформативнішими показниками працездатності та надійності операторської діяльності за даними літератури є рівень функціонального стану спеціаліста, стійкість, швидкість та точність його реакції $[11,17]$, зокрема, швидкість і точність реакції на рухомий об’єкт (PРО) [9], то було спеціально створено комп'ютерну методику для оцінки параметрів РPO [6].

Обстежуваному пропонували за допомогою двох заздалегідь довільно обраних клавіш клавіатури комп'ютера відзначати швидким натисканням, відповідної до напрямку руху маркера (стрілки, довжиною 1,5 см, що рухається на екрані монітора праворуч або ліворуч), клавіші в момент перетинання ним вертикальної лінії, розташованої по середині екрану. Правила руху маркера були наступними:

- маркер виникає й рухається прямолінійно від краю до краю оглядового діапазону, перетинаючи в центрі вертикальну лінію й безупинно продовжуючи надалі свій рух;

- вибір напрямку руху маркера (праворуч чи ліво руч) підкоряється рівномірному закону розподілу випадкових величин.

Дослідження проводиться у три етапи:

Перший етап - пробний режим тестування 3 пред'явленням 20 подразників. Швидкість руху маркера стала і дорівнює 60 мм/с.

Другий етап - режим тестування з «зворотним зв'язком» (коли швидкість руху маркера в наступному випробуванні збільшується на $10 \%$ у разі «вірної» реакції і зменшується на ту саму величину при «помилковій» діï) і пред’явленням 50 подраз- 
ників та виявленням найбільшої швидкості маркера $\left(\mathrm{K}_{1}, \mathrm{мм} / \mathrm{c}\right)$. «Вірною» слід вважати таку реакцію, коли натискання клавіші здійснюється відповідно до напрямку руху маркера та відбувається під час його знаходження в двосторонньому п'ятиміліметровому довірчому інтервалі відносно вертикальної лінії.

Третій етап - пред’явлення подразників з різною швидкістю руху маркера з чотирма рівнями складності завдань $\left(\mathrm{K}_{1}-10 \mathrm{mм} / \mathrm{c} ; \mathrm{K}_{1}\right.$ мм/ $; \mathrm{K}_{1}+10 \mathrm{mм} / \mathrm{c}$; $\mathrm{K}_{1}+20$ мм/с), кожне з яких пред'являлось випадковим чином 3 однаковою ймовірністю. Загальна кількість окремих елементів у завданні -80 , тобто по 20 для кожного з рівнів складності завдань.

Для аналізу даних було використано величини відхилення маркера від вертикальної лінії на третьому етапі дослідження при оптимальному навантаженні (II складність) та при надмірному навантаженні (IV складність) у сантиметрах. Відповідно знаком «-» позначали передчасне натиснення клавіші (до стикання стрілки з лінією), а знаком «+»- запізніле. Додатково розглядали показники відповідно до руху маркера: ліворуч (натиснення клавіші правою рукою) - «L-» та праворуч « $\mathrm{R}+»($ натиснення клавіші лівою рукою).

Аналіз отриманих результатів проводили методами варіаційної статистики, дискримінантного та кластерного аналізу 3 використанням пакетів LibreOffice (writer, calc та impress) 4.1.3.2 та Rcmdr 1.9-5, для візуалізації даних додатково використовували пакет SciDAVis 0.2.4.

\section{Результати дослідження та їх обговорення}

При аналізі результатів РРО встановлено майже повну відсутність помилкових натиснень клавіш під час руху маркера не залежно від його напрямку. Тому як характеристику надійності операторської діяльності було обрано точність РPO, що може також надати цінну інформацію про іiї кількісні та якісні параметри.

У результаті аналізу отриманих даних виявлено неоднорідність реакцій на рухомий об'єкт, яка проявляється як у часі реагування (передчасний або запізнілий тип реакції), так і напрямку руху (зліва направо чи навпаки). При підвищенні навантаження точність РРО очікувано зменшується, але це явище відбувається лише для запізнілого типу реакції незалежно від напрямку руху маркера (рис. 1). Оскільки за даними ряду авторів $[13,16]$ реакції передчасно-

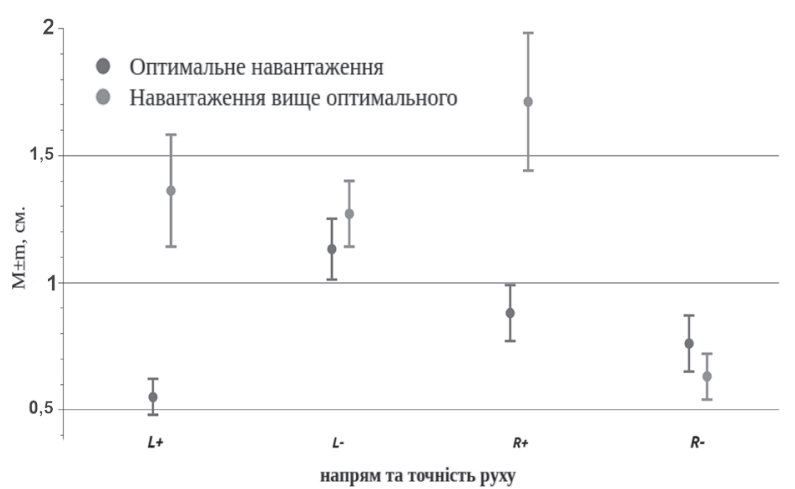

Рис. 1. Точність реакції на рухомий об'єкт залежно від ступеня навантаження

го натиснення при РPO характеризують переважання процесу збудження, а запізнення $-€$ індикатором переважання процесу гальмування в ЦНС, отримані результати свідчать про переважання гальмівних процесів у ЦНС, у той час як показники передчасної реакції майже не змінюються в обох випадках інтенсивності інформаційного навантаження.

Більш ретельний аналіз отриманих даних (табл. 1) показав наявність достовірної різниці точності запізнілих $\mathrm{PPO}$, а також у деяких випадках $(\mathrm{R}+)$ при надмірному інформаційному навантаженні неоднорідність отриманих даних за коефіцієнтами асиметрії та ексцесу.

Це може свідчити про наявність певної підгрупи осіб з іншою стратегією реагування на рухомий об'єкт при надмірному інформаційному навантаженні. Для виділення цієї підгрупи осіб було застосовано кластерний аналіз (за методом К-середніх). У результаті кластеризації отримано дві суттево різні за показниками точності РPO підгрупи осіб. Підгрупа I - 60 \% осіб з більш високою надійністю переробки інформації (краща точність РPO) та підгрупа II, що характеризується менш надійним виконанням РPО (табл. 2).

Дослідження профілів показників РPО, що отримані при візуалізації даних (рис. 2), дозволяє відмітити, що форма розміщення показників підгрупи I майже не змінюеться, однаково пропорційно збільшуючись при підвищенні навантаження. Проте в досліджуваних з підгрупи II під дією інформаційного навантаження відбувається більш значне зрушення показників затримки реакції. Причому показники навіть при оптимальному навантаженні майже в два рази перевищують показники в представників підгрупи I. На нашу думку, таке явище може свідчити 
Характеристика точності реакції на рухомий об'єкт при різних напрямках руху маркера

Таблици 1 та ступенях складності

\begin{tabular}{|l|c|c|c|c|}
\hline \multirow{2}{*}{$\begin{array}{c}\text { Iнтенсивність } \\
\text { інформаційного } \\
\text { навантаження }\end{array}$} & $\begin{array}{c}\text { Напрямок та } \\
\text { вчасність PPO }\end{array}$ & $\begin{array}{c}\mathbf{P P O}, \mathbf{c m} \\
\mathbf{( M} \pm \mathbf{m})\end{array}$ & $\begin{array}{c}\text { Коефіціснт } \\
\text { асиметрії (As } \pm \mathbf{m})\end{array}$ & $\begin{array}{c}\text { Коефіціснт ексцесу } \\
\mathbf{( E x} \pm \mathbf{m})\end{array}$ \\
\hline \multirow{3}{*}{$\begin{array}{l}\text { Оптимальне інформаційне } \\
\text { навантаження }\end{array}$} & $\mathrm{L}+$ & $0,55 \pm 0,07^{* *}$ & $0,39 \pm 0,41$ & $0,96 \pm 0,75$ \\
\cline { 2 - 5 } & $\mathrm{L}-$ & $1,13 \pm 0,12$ & $0,63 \pm 0,41$ & $2,47 \pm 0,75^{*}$ \\
\cline { 2 - 5 } & $\mathrm{R}+$ & $0,88 \pm 0,11^{* *}$ & $0,59 \pm 0,41$ & $1,42 \pm 0,75$ \\
\hline \multirow{2}{*}{$\begin{array}{l}\text { Навантаження вище } \\
\text { оптимального }\end{array}$} & $\mathrm{R}-$ & $0,76 \pm 0,11$ & $0,58 \pm 0,41$ & $1,56 \pm 0,75$ \\
\cline { 2 - 5 } & $\mathrm{L}+$ & $1,36 \pm 0,22$ & $1,18 \pm 0,41$ & $1,61 \pm 0,75$ \\
\cline { 2 - 5 } & $\mathrm{L}-$ & $1,27 \pm 0,13$ & $0,74 \pm 0,41$ & $0,98 \pm 0,75$ \\
\cline { 2 - 5 } & $\mathrm{R}+$ & $1,71 \pm 0,27$ & $1,47 \pm 0,41^{*}$ & $2,67 \pm 0,75^{*}$ \\
\hline
\end{tabular}

Примітка. *Достовірне відхилення від нормального розподілу за показниками асиметрії та ексцесу;

**достовірність різниці середніх значень показників точності РРО при різних ступенях інформаційного навантаження за критерієм Стьюдента на рівні р <0,001.

про те, що для підгрупи I притаманним є виразніша врівноваженість нервових процесів, у той час як для II підгрупи притаманним $є$ превалювання процесів збудження в ЦНС, що віддзеркалюється на загальних результатах дослідження.

He можна також залишити поза увагою те явище, що під дією навантаження показники передчасного натиснення клавіш у підгрупі II стають навіть кращими, ніж у підгрупі I, що також може вказувати на відносне посилення процесів гальмування в нервових центрах та відбивається не тільки в збільшенні часу запізнілого типу реакції, але й зменшенні часу передчасного типу. Таким чином, найдостовірнішими критеріальними ознаками диференціації отриманих підгруп є показники $\mathrm{R}+$.

Для подальшого вивчення особливостей реагування на рухомий об'єкт у різних підгрупах нами було вивчено зв'язок між показниками тесту РРО, а саме показниками при підвищеному інформаційному навантаженні та показниками при оптималь- ному навантаженні. Це дало змогу виявити декілька важливих моментів, які можуть вказувати на принципово різну структуру реагування першої та другої підгруп на збільшення навантаження при проходженні тесту РPO (рис. 3).

Насамперед звертає на себе увагу несподіваність напрямків руху кореляції. Очікуваний зв'язок «напрямок-знак» формується тільки в представників підгрупи I за показниками руху стрілки ліворуч. B інших випадках збільшення показника $(\mathrm{L}+)$ при оптимальному навантаженні може достовірно спричинити зниження (покращання) показника (L-'). У підгрупі I існує сильний позитивний зв'язок між показниками передчасної реакції правої руки та лівої руки при різному інформаційному навантаженні. Причому відмічається феномен «перехрестя» - двонаправлена зміна стратегії в підтримці надійного виконання роботи в режимі надмірного інформаційного навантаження. Таким чином, забезпечення надійного виконання тесту при висо-

Таблици 2

Порівняльна характеристика точності реакції на рухомий об'єкт в осіб різних підгруп військовослужбовців залежно від інтенсивності інформаційного навантаження

\begin{tabular}{|l|c|c|c|c|}
\hline \multirow{2}{*}{$\begin{array}{c}\text { Напрям та } \\
\text { вчасність } \\
\text { PPO }\end{array}$} & \multicolumn{3}{|c|}{ Статистичні показники результатів тестування підгруп, см (M \pm m) } \\
\cline { 2 - 5 } & Оптимальне інформаційне навантаження & \multicolumn{2}{|c|}{ Навантаження вище оптимального } \\
\hline $\mathrm{L}+$ & I підгрупа & II підгрупа & I підгрупа & II підгрупа \\
\hline $\mathrm{L}-$ & $0,34 \pm 0,05^{* *}$ & $0,85 \pm 0,06$ & $0,65 \pm 0,09 * * *$ & $2,43 \pm 0,20$ \\
\hline $\mathrm{R}+$ & $1,04 \pm 0,14$ & $1,27 \pm 0,06$ & $1,32 \pm 0,16$ & $1,19 \pm 0,10$ \\
\hline $\mathrm{R}-$ & $0,52 \pm 0,03 * * *$ & $1,43 \pm 0,10$ & $0,93 \pm 0,12 * *$ & $2,89 \pm 0,29$ \\
\hline
\end{tabular}

Примітка. **, ***Достовірність різниці відповідних середніх значень точності РРО різних підгруп за критерієм Стьюдента відповідно на рівні $p<0,005 ; p<0,001$. 


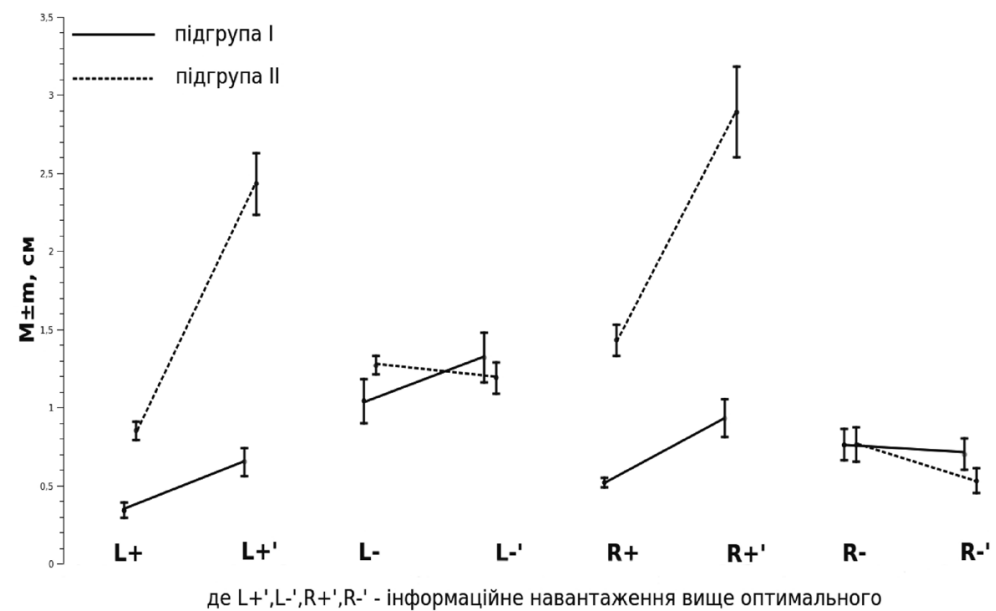

Рис. 2. Профіль показників точності реакції на рухомий об'єкт у різних підгруп при неоднаковому інформаційному навантаженні

кому інформаційному навантаженні обумовлено врівноваженістю патернів міжпівкульної асиметрії нервових процесів у ЦНС. Тому показники «L-», «R-» та відповідні до них «L-'», «R-'», не дивлячись на відсутність достовірності міжгрупової різниці середніх значень, є важливими характеристиками в прогнозуванні надійності операторської діяльності при впливі різного за інтенсивністю інформаційного навантаження.

У підгрупі II значима кореляція відмічається в наявності зв'язку тільки показників, отриманих при натисканні правою рукою при оптимальному навантаженні та лівою рукою при навантаженні вище оптимального для відповідних напрямків руху маркера. Таку залежність можна охарактеризувати як «зміщення у бік», що є проявом неврівноважених патернів міжпівкульної асиметрії. Тобто, забезпечення надійнішого виконання тесту PPO при оптимальному навантаженні залежить від напруженого функціонування правої півкулі мозку, а при надмірному інформаційному навантаженні - лівої.

Також відмінна сама структура взаємозв'язків, яка в I підгрупі різноспрямована (як пряма, так і зворотна), більше розгалужена та кількісно переважає над структурою підгрупи II. Це може свідчити про більш виражену напруженість функціонального стану (стану активної мобілізації) при збільшенні інформаційного навантаження. У II підгрупі відмічається варіант розвитку «однобічної спрямованості», тобто при збільшенні навантаження переважають більш консервативні механізми в підтримці надійного виконання операторської діяльності, що не дає змоги представникам цієї підгрупи швидко пристосовуватись при зміні складності завдань тощо.

Для побудови розв'язувальних правил 3 метою встановлення критеріїв диференціації корабельних спеціалістів за рівнем надійності професійної діяльності було застосовано покроковий дискримінантний

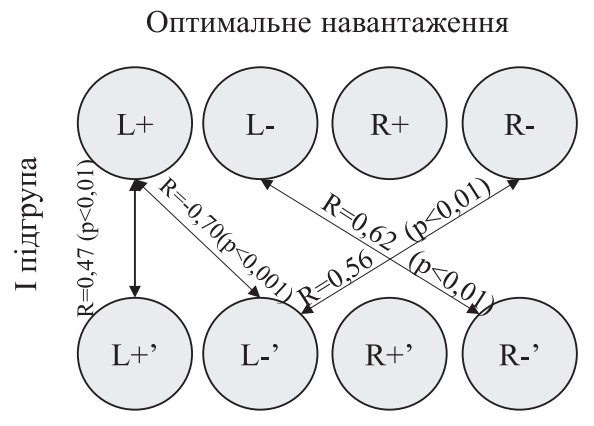

Навантаження вище оптимального

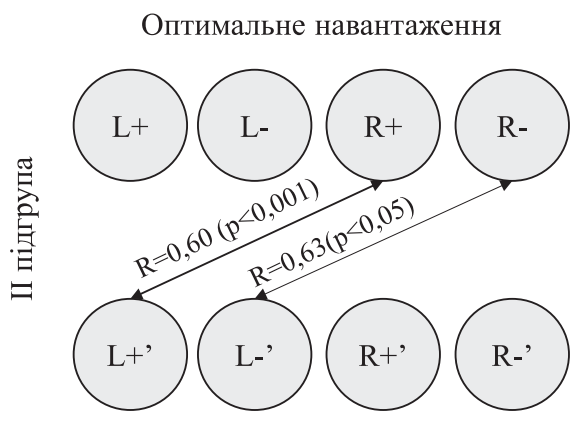

Навантаження вище оптимального

Рис. 3. Значимі кореляційні зв'язки точності реакції на рухомий об'єкт у підгрупах I та II 
аналіз досліджених параметрів РРО. Такий прийом дозволив побудувати наступні функції $(\mathrm{p}<0,01)$ :

$$
\begin{aligned}
\mathrm{U} 1= & -6,65+7,64 \cdot\left\langle\mathrm{R}+»+3,11 \cdot\left\langle\mathrm{R}-{ }^{\prime} »+\right.\right. \\
& 7,63 \cdot\langle\mathrm{L}-» ; \\
\mathrm{U} 2= & -24,51+26,32 \cdot\left\langle\mathrm{R}+\gg-6,39 \cdot\left\langle\mathrm{R}-{ }^{\prime} »+\right.\right. \\
& 14,14 \cdot \ll \mathrm{L}-»,
\end{aligned}
$$

де показники точності $\mathrm{PPO}$ : «R+»- середня відстань маркера після вертикальної лінії при його русі праворуч при оптимальному навантаженні, «R-'»- середня відстань маркера до вертикальної лінії при його русі праворуч при надмірному навантаженні, «L-» - відстань маркера до вертикальної лінії при його русі ліворуч при оптимальному навантаженні в сантиметрах.

При виконанні умови $\mathrm{U} 1 \leq \mathrm{U} 2-$ прогноз надійності професійної діяльності є низьким, в іншому випадку - високий. При перевірці на точність запропонованих розв'язувальних правил виявлено лише один випадок неспівпадання, що є досить гарним показником (96,66 \%) для дискримінантних функцій.

Узагальнюючи проведені нами дослідження, слід зазначити і те, що вони кореспондують з думкою інших вчених. Так, у роботі [7] зазначається, що за показниками $\mathrm{PPO}$ можна в певній мірі судити про стабільність функціонування ЦНС і опосередковано про надійність операторської праці, як онтогенетично обумовленої психофізіологічної якості людини. Крім того, точність РРО пов'язана з силою, рухливістю та лабільністю ЦНС, що дозволяє використовувати іiі як індикатор психічних станів, а також може свідчити про психічний стан пацієнта (астенія, тривожність тощо), та, крім цього, характеризуе особливості інтеграційної функції мозку в сприйнятті часу та простору, надає змогу оцінити психічний стан у цілому [15]. У дослідженнях Д. С. Репіна та співавторів [14] зазначено, що навіть невеликі зміни в індивідуальних показниках часу PРО можуть вказувати на суттеві функціональні перебудови в організмі людини, що впливають на якість здійснення професійних обов'язків. Є. П. Ільїн [5] у своїй праці робить висновок, що показники точності PРО покращуються паралельно зростанню рівня тренованості та технічної майстерності людини й одночасно є чутливим індикатором функціонального стану нервової системи. Величина варіаційного розмаху РPO може вважатися цінним засобом визначення емоційної стійкості оператора, вона корелює з варіативністю інших психічних та вегетативних функцій. Чим менша величина варіаційного розмаху $\mathrm{PPO}$, тем менша варіативність інших показників, і стабільніша професійна діяльність [12]. Отримані в роботі [8] дані щодо збільшення точності реакцій на рухомий об'єкт і зменшення їхньої варіативності під впливом ігрового біокерування свідчать про оптимізацію балансу нервових процесів, що покращує можливості чітко передбачити можливі траєкторії переміщення в просторі, забезпечувати швидкість дій.

Таким чином, точність реакції на рухомий об'єкт $€$ складним просторово-часовим рефлексом, що може використовуватись як тест для визначення взаємообумовленості процесів збудження та гальмування в корі головного мозку як у стані оптимального навантаження, так і під впливом надмірного інформаційного навантаження, а також важливою прогностичною характеристикою надійності професійної діяльності рульових матросів ВМС 3С України. У роботі показано особливості зміни механізмів підтримки високої надійності операторської діяльності при різній інтенсивності інформаційного навантаження при тестуванні PРО у осіб з суттево різною її точністю. Крім того, за параметрами $\mathrm{PPO}$ запропоновані критерії для прогнозування високої надійності професійної діяльності рульових матросів, що враховують інтенсивність інформаційного навантаження та врівноваженість патернів міжпівкульної асиметрії нервових процесів у головному мозку людини і можуть використовуватись при здійсненні психофізіологічної експертизи зазначеного контингенту осіб.

\section{Висновки}

1. Встановлено, що при зростанні інтенсивності переробки інформації в рульових матросів достовірно погіршуються показники точності реакції запізнілого типу не залежно від напрямку руху рухомого об'єкта, що свідчить про негативний вплив гальмівних процесів у центральній нервовій системі на надійність переробки інформації.

2. Виділення двох підгруп осіб з суттєвою різницею параметрів точності реакцій на рухомий об’єкт запізнілого типу, яка суттево збільшується при надмірному інформаційному навантаженні, дозволило виявити існування різних механізмів та стратегій при забезпеченні високої надійності діяльності під час дослідження реакції на рухо- 
мий об’єкт у рульових матросів, що обумовлено в осіб з кращими показниками точності реакцій (60\%) проявами врівноваженості чи неврівноваженості - у осіб з гіршими показниками точності реакцій - патернів міжпівкульної асиметрії нервових процесів у головному мозку та різною напруженістю регуляторних процесів у центральній нервовій системі.

\section{Література}

1. Безпека авіації / Бабак В. П., Харченко В. П., Максимов В. О. [та ін.]: Під ред. В. П. Бабака. - К. : Техніка, 2004. - 584 с.

2. Грицевский М. А. Влияние сложности задач управления на уровень активации физиологических функций оператора при работе в режиме ожидания / Грицевский М. А., Зайцева Ж. И. // Физиология человека. - 1985. - Т. 11, № 3. - С. 504-510.

3. Єна А. І. Актуальні проблеми і організаційні засади психофізіологічного забезпечення Збройних Сил України / Єна А. I. // Військова медицина України. - 2001. - Т. 1, № 1. - С. 54-62.

4. Єна А. І. Особливості формування синдрому професійного вигорання серед осіб, робота яких пов'язана з небезпекою / Єна А. І., Кальниш В. В., Кравчук В. В. // Актуальні проблеми психології: Зб. наук. праць Інституту психології ім. Г. С. Костюка АПН України, за ред. С. Д. Максименка. - 2004.- Т. 7, № 3. - С. 87-95.

5. Ильин Е. П. Психомоторная организация человека / Е. П. Ильин. - СПб. : Питер, 2003. - 384 с.

6. Кальниш В. В. Удосконалення методології визначення психофізіологічних характеристик операторів / Кальниш В. В., Швець А. В. // Український журнал з проблем медицини праці. - 2008. - Т. 16, № 4. - С. 49-54.

7. Характеристика временных свойств человека (физиологические аспекты) / Корягина Ю. В., Малко А. И., Бугаева Н. А. Колбасюк И. И. // Успехи современного естествознания. - 2003. - № 11. - С. 59-60.

8. Кузнецова Л. А. Исследование влияния игрового биоуправления на психофизиологические показатели спортсменов-единоборцев с нарушением вегетативного статуса / Кузнецова Л. А., Гувакова И. В. // Бюллетень сибирской медицины, Иркутск. - 2013. Т. 12, № 2. - С. 211-218.

9. Макаренко М. В. Основи професійного відбору військових спеціалістів та методики вивчення індивідуальних психофізіологічних відмінностей між людьми / М. В. Макаренко. - К. : Інститут фізіології ім. О. О. Богомольця НАН України, Науководослідний центр гуманітарних проблем ЗС України, 2006. - 395 c.
3. Розроблені розв'язувальні правила за характеристиками точності реакції на рухомий об'єкт достатні для прогнозування високої надійності професійної діяльності рульових матросів-операторів з вірогідністю 96,66 \% та можуть бути використані під час їхного динамічного психофізіологічного контролю та здійснення заходів психофізіологічної експертизи, чи професійного добору.

10. Малинецкий Г. Г. Наука о риске и жизнь / Малинецкий Г. Г. // Проблемы безопасности при чрезвычайных ситуациях. - 2001. - № 3. - С. 59-72.

11. Мороз М. П. Прогнозирование работоспособности операторов с помощью метода многомерного статистического анализа / Мороз М. П., Тихонов М. Н. // Физиология человека. - 1992. - Т. 18, № 2. - С. 36-44.

12. Мыльникова И. В. Психофизиологические особенности юношей допризывного возраста с различным уровнем интенсивности спортивных нагрузок / Мыльникова И. В., Ефимова Н. В. // Вестник Российской военно-медицинской академии. - 2013. T. 42, № 2. - С. 96-99.

13. Песошин А. В. Информационные технологии автоматизации оценки соотношения возбуждения и торможения в центральной нервной системе / Песошин А. В. // Системы управления и информационные технологии. - 2007. - Т. 30, № 4. - С. 275-279.

14. Репин Д. С. Микропроцессорный комплекс оценки времени реакции человека на движущийся объект / Репин Д. С., Дегтярев Н. В., Петухов И. В. // Фундам. исследования. - 2011. - № 8. - С. 167-171.

15. Сурнина О. Е. Половые и возрастные различия времени реакции на движущийся объект у детей и взрослых / Сурнина О. Е., Лебедева Е. В. // Физиология человека. - 2001. - Т. 27, № 4. - С. 56-60.

16. Цагарелли Ю. А. Теория и практика системной диагностики человека / Ю. А. Цагарелли. - Казань : Татглимат, 2002. - 168 с.

17. Цуканов Б. И. Восприятие времени и психологическая устойчивость личности / Цуканов Б. И. // Психологическая устойчивость профессиональной деятельности. - Москва-Одесса, 1984. - С. 180-182.

18. Цуканов Б. И. Анализ ошибки восприятия длительности / Цуканов Б. И. // Вопросы психологии. 1985. - № 3. - С. 149-154.

19. Шафран Л. М. Теория и практика профессионального психофизиологического отбора моряков / Леонид Шафран, Эдуард Псядло. - Одесса : «Феникс», 2008. -292 c.

20. Veltman H. Operator functional state assessment / Veltman H., Wilson G., Burov O. // Cognitive load. NATO Science Series RTO-TR-HFM-104. - Brussels, 2004. - P. 97-112. 


\section{References}

1. Babak, V. P., Kharchenko, V. P., Maksimov, V. O. et al. 2004, Safety of aviation (Edited by V. P. Babak). Kyiv : Tekhnika, 584 p. (in Ukrainian).

2. Gritsevsky, M. A., Zaitseva, Zh. I. 1985, "Influence of task complexity on the activation level in management of physiological functions of an operator at work in an expectation mode», Human physiology, Vol. 11, no. 3, pp. 504-510 (in Russian).

3. Ena, A. I. 2001, "Actual problems and organizational bases of psychophysiological provision of Ukrainian Armed Forces", Military medicine of Ukraine, no. 1, pp. 54-62 (in Ukrainian).

4. Ena, A. I., Kalnysh, V. V., Kravchuk, V. V. 2004, «Features of professional burning out syndrome formation among persons, whose work is connected with danger", Actual problems of psychology: Digest of the G. S. Kostyuk Institute of Psychology of UAPS (ed. Maksimenko S. D), no. 3, pp. 87-95 (in Ukrainian).

5. Ilyin, E. P. 2003, Human psychomotor organization. $\mathrm{SPb}$ : Piter, 384 p. (in Russian).

6. Kalnysh, V. V., Shvets, A. V. 2008, «Improvement of methodology of detection of an operators' psychophysiological characteristics", Ukrainian J. Occup Health, Vol. 16, no. 4, pp. 49-54 (in Ukrainian).

7. Koryagina, J. V., Malko, A. I., Bugayeva, N. A. Kolbasuk, I. I. 2003, "Characteristic of a man's time properties (physiological aspects)", Successes of modern natural sciences, no. 11, pp. 59-60 (in Russian).

8. Kuznetsova, L. A., Guvakova, I. V. 2013, "Research of game biomanagement effect on psychophysiological indices of single combat sportsmen with disorders of the vegetative status", Bulletin of the Siberian medicine, Irkutsk ,Vol. 12, no. 2, pp. 211-218 (in Russian).

9. Makarenko, N. V. 2006, The fundamentals of occupational selection of military specialists and a method of studying individual psychophysiological differences in humans. O. O. Bogomolets Institute of Physiology of NAS of Ukraine, Research Center of humanitarian problems of UAF of Ukraine, Kyiv, 395 p. (in Ukrainian).
10. Malinetsky, G. G. 2006, "Science about risk and life», Problems of safety in extreme situations", no. 3, pp. 59-72 ( in Russian).

11. Moroz, M. P., Tikhonov, M. N. 1992, "Forecasting operators' working capacity by the method of multidimensional statistical analysis", Human physiology, no. 2, pp. 36-44 (in Russian).

12. Mylnikova, I. V., Yefimova, N. V. 2013, "Psychophysiological features of draftees with various levels of sports loading intensity", Herald of Russian Military-medical Academy, no. 2, pp. 96-99 (in Russian).

13. Pesoshin, A. V. 2007, "Information technologies in automatic estimation of the relation in activation and inhibition of the central nervous system", Controlling systems and information technologies, no. 4, pp. 275279 (in Russian).

14. Repin, D. S., Degtaryev, N. V., Petukhov, I. V. 2011 , "Microprocessor combined estimation of the time man's reaction on the moving object", Fundamental studies, no. 8, pp. 167-171 (in Russian).

15. Surnina, O. E, Lebedeva, E. V. 2001, "Sexual and age differences in time reaction to the moving object in children and adults", Human physiology, Vol. 27, no. 4, pp. 56-60 (in Russian).

16. Tsagarelly, Y. A. 2002, Theory and practice of a man's system diagnostics. Kazan : Tatglimat, 168 p. (in Russian).

17. Tsukanov, B. I. 1984, Perception of time and psychological stability of an individual, Psychological stability in occupational work. Moscow-Odessa, pp. 180182 (in Russian).

18. Tsukanov, B. I. 1985, "Analysis of an error in perception of duration", Questions of Psychology, no. 3, pp. 149-154 (in Russian).

19. Shafran, L., Psyadlo, E. 2008, Theory and practice of occupational psychophysiological selection of seamen (Eds. L. Shafran, E. Psyadlo). Odessa:Phoenix, 292 p. (in Russian).

20. Veltman, H., Wilson, G., Burov, O. 2004, Operator functional state assessment Cognitive load. NATO Science Series RTO-TR-HFM-104. Brussels, pp. 97-112.

\section{Швец А. В., Аукьянчук И. А. \\ ПСИХОФИЗИОЛОГИЧЕСКИЕ ОСОБЕННОСТИ ПРОГНОЗИРОВАНИЯ НААЕХКНОСТИ ПРОФЕССИОНААЬНОЙ АЕЯТЕАЬНОСТИ РУАЕВЫХ МАТРОСОВ ПО ПОКАЗАТЕАजМ PЕАКИИИ НА АВИХКУUИЙСЯ ОБЪЕКТ}

Научно-исследовательский институт проблем военной меАицины Украинской военно-меАицинской акамемии, г. Киев

Введение. Исследования, направленные на достижение высокого уровня надежности профессиональной деятельности операторов, в частности рулевых матросов; являются актуальными в современной медицине, психофизиологии и эргономике труда.

Цель исследования. На основании исследования закономерностей функционирования центральной нервной системы при воздействии информационной загрузки разной степени интенсивности разработать подходы к прогнозированию надежности операторской деятельности рулевых матросов по характеристикам реакции на движущийся объект. 
Материалы и методы исследования. Для выполнения данной работы была исследована группа рулевых матросов (30 мужчин возрастом 22-24 года). Для определения характеристик реакции на движущийся объект (РДО) при различной информационной нагрузке была создана специальная компьютерная программа. Как характеристику надежности операторской деятельности выбрано показатель точности РДО в зависимости от своевременности реакции, направления движения маркера и различного уровня информационной нагрузки.

Результаты. У рулевых матросов выявлено достоверное ухудшение показателей точности РДО тормозного типа при повышении информационной нагрузки, не зависимо от направления движения маркера. Выделено две существенно разные подгруппы лиц по уровню точности РДО, которые имеют разные стратегии поддержания надежного выполнения операторской деятельности, что обусловлено особенностями проявления межполушаровой асимметрии, а также количественной и качественной структурой взаимосвязей показателей точности РДО при разной интенсивности информационной нагрузки. Наличие превалирования тормозных процессов в центральной нервной системе оказывает достоверное негативное воздействие на надежность переработки информации.

Bblводы. 1. По параметрам точности РДО тормозного типа выделено две подгруппы респондентов, которые существеннее различались при чрезмерной информационной нагрузке. 2. Выявлено существование разных механизмов и стратегий обеспечения высокой надежности переработки информации, в основе которых находятся проявления уравновешенности или неуравновешенности паттернов межполушарной асимметрии нервных процессов в головном мозге и различная напряженность регуляторных процессов в центральной нервной системе соответственно у индивидуумов с лучшими (60 \%) и худшими (40 \%) показателями точности РДО. 3. Разработанные решающие правила по показателям точности РДО достаточны для прогнозирования высокой надежности профессиональной деятельности рулевых матросов с точностью 96,66 \%.

Ключевые слова: надежность профессиональной деятельности, реакция на движущийся объект, рулевые матросы

\title{
Shvets A. V., Lukyanchuk I. A. \\ PSYCHOPHYSIOLOGICAL FEATURES OF RELIABILITY FORECASTING FOR STEERING SAILOR OCCUPATIONAL ACTIVITY USING THE REACTION ON THE MOVING OBJECT
}

\author{
Scientific Research Institute of Problems of Military Medicine of Ukrainian Military and Medical Academy, Kyiv
}

Introduction. The researches, directed at achievement of operators' high level reliability, steering sailor, in particular, are actual in modern psychophysiology ergonomics and occupational medicine.

Purpose of the study. On the basis of studying regularities of functioning of the central nervous system under the influence of information loading of different degree of intensity to develop approaches to forecasting the reliability of camera activity of ship experts by characteristics of reaction to the moving object.

Materials and methods. The group of steering sailor (30 men 22-24 years of age) was investigated for performing the presented work. A special computer program for revealing characteristics of reaction on moving object (RMO) in various information loadings has been created. The indicators of RMO accuracy, depending on the reaction timeliness, movement direction of a marker and various level of information loading were chosen as the characteristic of reliability of an operator's activity.

Results. The significant deterioration of indicators of inhibitory type of RMO accuracy among steering sailor has been revealed under the increase of information loading, which does not depend on the RMO direction. Two significantly different subgroups of individuals by the level of RMO accuracy, having different maintenance strategy to reliable performance of operator's activity, caused by peculiarities of manifestation of the interhemispheric asymmetry and, also, quantitative and qualitative structure of interrelations of RMO accuracy indicators under different intensity of information loading. The presence of prevalence of inhibitory processes in the central nervous system can cause a significant do negative influence on reliability of the information processing. Conclusion. Two subgroups of respondents, different by excessive information loading more essentially by parameters of inhibitory type of RMO accuracy have been separated. There was revealed the existence of different mechanisms and strategies of high reliability maintenance of information processing, based on the steadiness or unsteadiness of interhemispheric asymmetry patterns of nervous processes in the brain and different intensity of regulatory processes in the central nervous system in individuals with the best $(60 \%)$ and the worst (40\%) indicators of RMO accuracy, respectively. The developed decisive rules by indicators of RMO accuracy are sufficient for forecasting the high reliability of steering sailor occupational activity with $96,66 \%$ accuracy.

Key words: reliability of occupational activity, reaction to the moving object, steering sailor

Надійшла: 03.02.2014 p.

Контактна особа: Швець Андрій Володимирович, кандидат медичних наук, старший науковий співробітник, науково-дослідний відділ психофізіології людини в особливих умовах, Науково-дослідний інститут проблем військової медицини Української військово-медичної академії, буд. 1, 11-та лінія, м. Ірпінь, 08203.

Електронна пошта: avshvets@mail.ru 